\title{
The Role of Judges in the Performance of Italian Courts
}

\author{
Marilene Lorizio \\ Associate Professor in Economics, Department of Law, University of Foggia \\ E-mail: marilene.lorizio@unifg.it
}

\author{
Annamaria Stramaglia \\ Lecturer in Economics, Department of Law, University of Foggia \\ E-mail: annamaria.stramaglia@unifg.it
}

Received: January 31, 2016 Accepted: February 17, 2016

doi:10.5296/ber.v6i1.9671ＵRL: http://dx.doi.org/10.5296/ber.v6i1.9671

\begin{abstract}
The paper analyses the contribution judges make to the supply of justice in Italian district courts. A Multilevel Growth Model (MGM) was applied to the analysis. The results show several differences in productivity in Italian district courts, which may be linked to (i) differences in the contribution of judges (ii) poor rational organization of resources and/or (iii) a limited use of case management techniques.
\end{abstract}

Key words: judicial system, individual incentives, justice supply

\section{Introduction}

The debate between justice and its performance is an important issue both at international and national level and involves several disciplinary approaches. In Italy, over the last few years many legislative measures have been carried out in order to address the most critical aspects of the system. One of the most recent refers to the reorganization of the juridical geography resulting in the closure of smaller judicial offices ${ }^{1}$. This is in line with the economic principles of efficient allocation of resources and of economies of scale and specialization ${ }^{2}$.

This paper investigates the theory that differences in the level of human resources (i.e. judges) may explain the difference in performance among Italian courts. Some significant factors that determine the supply of justice and influence the performance of the judicial system in Italy are

\footnotetext{
${ }^{1}$ Decree 19 febbraio 2014, n. 14 "Disposizioni integrative, correttive e di coordinamento delle disposizioni di cui ai decreti legislativi 7 settembre 2012, n. 155 e 7 settembre 2012, n. 156, tese ad assicurare la funzionalità degli uffici giudiziari".

2 The reform of judicial geography eliminates a thousand small sized offices. The total savings estimated would be equal to 55 million euros for 2014 and 95 million euros for the following years.
} 
discussed, as is the role of the judges, both theoretically and by applying an empirical estimation.

The authors believe this paper will provide a useful contribution to the national and international debate on the subject at a time when there are many regulatory interventions in the judiciary. This paper is part of a wider research study on the subject of justice (cfr. Gurrieri and Lorizio, 2014a; 2014b; 2015; Stramaglia, 2014), which involved stakeholders.

The poor performance of the judicial system - with particular reference to the length of proceedings - can be explained from both a macroeconomic and a microeconomic perspective. In the former case, this is due to the failure to achieve a balance between supply and demand for justice, as in the supply of goods and services, both private and public (cfr. Mitsopoulos and Pelagidis, 2010). An analysis of the possible causes of inefficiency may also focus on the micro level, i.e. taking into account the behavior of individual economic agents (cfr.: Marchesi, 2003; Buscaglia and Dakolias, 1999). On the supply side, this concerns the judges as well as all the support staff. This behavioural approach focuses on the individual incentives that lead to a mismatch between individual preferences and the performance of the system (Buscaglia, 2006). Judges play a critical role in determining the performance of the judicial system as they represent the most important input (labour force). They are the actors who are more involved in the pursuit of economies of specialization.

The paper is organized as follows. Section 1.2 presents a short review of the subject with particular reference to (i) individual incentives, especially reputation, and (ii) the role of the judge in determining the performance of the system. In this section, a Multilevel Growth Model (MGM) is presented which is then discussed in section 3. Section 4 presents the conclusions and policy implications.

\subsection{Literature Review}

\subsubsection{Judges and Individual Incentives}

The institutional context consists in "the rules of the game" which refer to social interaction. They influence the incentives system on which political, economic and social interactions are based. According to North, the institutions have an essential role because they "...reduce uncertainty by providing a structure to everyday life" (North 1990, p. 3). Institutions, however, are made up of individuals who may use the advantage of having information to increase personal utility by reducing the overall effectiveness of the institutional activity.

The state plays a central role in determining transaction costs since its activities include a) the definition of formal rules of the game (constitutions, laws, regulations); b) the provision of protective services for resolving disputes concerning contractual agreements; c) the creation, allocation and sanction of property rights through the policies and the production of public goods.

If justice is considered as a public service, then judges are the actors who determine the allocation of rights and their protection by applying the laws. Moreover, the costs related to their decisions, such as (i) the costs related to the length of time required to recognize the 
rights of the injured party (failure costs); (ii) the costs of justice (explicit and monetary); (iii) the implicit costs related to the final sentence that "makes the law", fall on the entire community.

The importance of the role of the judiciary has been emphasized and verified both at national and international level. It seems appropriate to implement mechanisms that push the actions of judges to converge with the efficiency of the system (cfr. among others: Rosales-López, 2008; Castro, 2009; Deyneli, 2011). This link is difficult because of the Italian legal system complexity and the excessive number of laws (objective cause) (Di Vita, 2010 and 2012).

Judges are not driven to administer justice quickly as their career advancement does not depend on either promptness or rapidity. This is also the case in the Italian system and is the reason why judges prefer to reach almost unimpeachable judgments. On this point, in reference to the German situation, Schneider (2005) underlines that unhooking the careers of judges from their judicial productivity and efficiency can lead the single magistrate to improve the quality of his judicial service.

There are incentives that lead individual judges to carry out provisions as accurately as possible, thus with a low probability of being rejected during the appeal. These incentives are called reputational incentives, and have been identified and analyzed particularly with reference to the common law jurisdictions (cfr. among others: Posner 1993, 2009; Miceli and Cosgel, 1994; Cohen et al., 2013). These types of incentives also seem to be present in the Italian justice system (cfr among others: Marchesi, 2003; Palumbo and Sette, 2006; Szego, 2008). There are also incentives to opportunistic behaviour, which consist in the strategic use of information in order to gain personal advantage (Williamson, 1985).

As regards Italy, Szego (2008) underlines that the mere existence of several judicial levels leads the courts of first instance to produce judgments in an extremely careful way, in order to highlight their competence and the high quality of their work and thus improve their reputation. (Castro, 2009). This type of incentive goes beyond the boundaries of the judicial sphere. In fact, it is more to do with the gratification received from the reputation linked to their own competence and skills. Extrajudicial assignments, therefore, (i) represent an improvement for a judge from a cultural point of view (such as academic teaching) and (ii) are an answer to the political needs of legal and judicial professionalism.

According to Posner, (cfr. among others: 1993, 2008), reputational incentives confer a benefit resulting from the work of the judge, in addition to that resulting from the status of the judge. "Being" a judge determines a financial benefit (earnings), while "doing" (well) the judge involves non-pecuniary benefits (prestige, reputation and esteem). This leads to two different considerations on judges and their work: (i) there is the incentive to produce accurate sentences with a low probability of being rejected (this incentive may not be in line with the efficiency and effectiveness of the system); (ii) their reputation/prestige materializes in extra-judicial assignments, which further improve their reputation.

If the behaviour of a judge is considered rational, then the previous considerations imply that there is a function of utility for the judge/agent. Based on Posner's considerations, it is possible 
that, in addition to income (which is a proxy of the amount of consumable goods and services) and leisure, the utility function of individual judges should also include another composite variable summarizing the reputation deriving from the work of a judge.

\subsubsection{Incentives and Length of Legal Disputes}

The length of legal disputes represents the greatest problem for justice systems. This is also true in Italy. This may be due to deviant behaviours of the actors who play a role both on the demand (lawyers and/or injured parties) and the supply side (judges).

On the supply side the question is why, on average, do judges take a long time to issue a sentence, especially Italian judges (in addition to the large number of unsettled disputes).

The causes may be objective, such as the difficulty of the legal system and the disproportionate number of laws, or subjective, such as the "choice" of the judge to take longer, according to the above-mentioned incentives theory. This theory is based on the hypothesis that the information is incomplete and asymmetrical leading to higher transaction costs. This also favours incentives to opportunistic behaviour.

Judges represent the necessary input in the production of judiciary services. They do not enjoy the direct benefits of their decisions and therefore have little incentive to invest time and resources in the rapid and effective protection of rights. They also have greater incentives to invest time and resources in looking for countervailing benefits (pecuniary or non-pecuniary) for themselves. Their ability to manage the court and define cases quickly is strongly linked to individual experiences and to the carrier incentives. Reputational incentives refer to an increase in social prestige and visibility awarded to a "good" judge, and exercise great influence at the individual level since they lead to career advancement. Indeed, judges pursue their aim to improve their reputation, which depends on their own juridical experiences and past judgments. In taking charge of original and advanced decisions, the single judge shows his ability to administer justice and reduce the probabilities of an appeal. A judgment of this type could, however, require a very long period. Greater prestige materializes in assignments - both paid and unpaid - and in extra-judicial areas (consulting, study commissions, teaching, conferences, etc.). In these areas, it is possible to increase the level of gratification beyond the purely judicial function. It should be noted that the incentive to issue a ruling as accurately as possible, even though not timely, is positively associated with the complexity of the regulatory framework.

\subsubsection{Judges and The Judicial System}

The number of judges is a key element in determining the performance of the whole system on the supply side, as they are the workforce of the sector. It is therefore reasonable to expect that an increase in the number of judges could have a positive impact on performance. This is because judges represent an input (the labor force) in the productive function of the judiciary, and an increase in number would also increase the output level of the system (even though the number of incumbent judges might create a "bottleneck").

The effect of the number of judges on the efficiency of the system may not be clear ex-ante. 
Following the approach based on a rational model of their behavior (cfr. Cooter, 1983; Posner, 1993 and 2008; Beenstock and Haitovsky, 2004), an increase in number could have the following uncertain outcomes: (i) the output of the judiciary increases due to the contribution of the new judges; (ii) the marginal productivity of the incumbent judges decreases. Therefore, the final effect of these opposite trends on the output and on the total productivity of the system will be uncertain.

Based on these considerations, several researchers assert that an increase in the number of judges may not be the solution to the problem (cfr. among others: Dakolias, 1999; Yeung and Azevedo, 2011). Some scholars have underlined that the productivity of judges directly varies with case-load pressure (cfr. among others: Beenstock and Haitovsky, 2004). Working under pressure requires the maximum use of work time and this reduces the average time for pronouncing a sentence. On the contrary, based on the equation that greater quantity equals low quality, other scholars highlight that this leads to a congestion effect, which has a negative impact on the quality of judgments (Murrell, 2001).

The organization of the workload of a judge is very important because the extensive use of best practices reduces the influence of individual preferences thus permitting faster judgments, at least where easier cases are concerned (Scott, 2006). Leonardi and Rancan (2010) point out that some measures are needed to improve the organizational aspects, such as greater use of information technologies and the adoption of best practices. With reference to the Brazilian Judiciary, Yeung and Azevedo (2011) have shown a relationship between efficiency in courts and the quality of their management, the organization of the workplace and staff motivation.

\subsection{Research Questions}

Several factors may contribute to the judicial system being understaffed and these play a role in both the demand and the supply side. When the problem of judicial system performance concerns the insufficient system of resources (mainly human resources), the simplest solution seems to be straightforward: more judges means more productivity and better system performance. This is because larger courts may exploit the advantages derived from economies of scale and specialization. However, according to the literature on the subject, the rational behaviour model of the judges suggests that the effect of such a conventional strategy is uncertain ex-ante.

Compared to international level the Italian system does not seem to be understaffed as far as the number of judges is concerned (CEPEJ, 2012) yet the productivity of the Italian judicial districts is different.

The question is whether it is possible to increase the efficiency of the courts by reducing the length of the proceedings but without reducing the quality of service. It is not yet clear if (i) a greater number of judges has a positive effect on the performance of the system or (ii) a greater number of judges is able to compensate for (or at least attenuate) the negative effect of individual incentives.

It is very difficult to apply an individual level of analysis in the Italian system because of the type of information required and the necessary respect for both the privacy and independence 
of the judges. Since it was not possible to verify subjective incentives, only objective data, which refer to a territorial level, have been analysed.

The empirical analysis aims to verify whether the number of judges at territorial level (the main workforce) plays a significant role in the performance of the system.

\section{Data Collection and Analysis}

The remit of judges may be a sensitive issue as it could be difficult to compare it with any other kind of administrative work. Nevertheless, any evaluation of the performance of the judicial system must also include judges and courts as (i) the judicial system is part of the public system and (ii) the judiciary are the key factor in protecting the rule of law. The role of judges therefore can be analysed at different levels. If applying the previously adopted theoretical approach, the individual level would be preferable because for each judge it would be theoretically possible to consider several factors, which contribute to individual productivity (i.e. reputational incentives, continuing education, etc.).

In order to try to estimate the impact the number of judges has on the performance of the system, a model was tested using data from the General Statistic Directorate of the Ministry of Justice database (DG-Stat), an office which belongs to SISTAN, as well as data on the number of judges obtained from the Superior Council of the Judiciary (C.S.M.). The data refer to both civil and penal law. In order to better highlight the role of judges at the sub-district level, the whole system was studied.

The empirical analysis focused on the 165 sub-districts, which make up the Italian justice system (at the upper level they are aggregated in 26 districts). This level of analysis is better suited to the aims of this paper as the differences in performance can be more clearly demonstrated at this territorial level. Data were collected for a 5 year period (2007-2011). This period was chosen based on the availability of uniform data referred to the pre-judicial geography reform period. Several work indicators, which describe the performance of the judges at sub-district level and show their contribution were calculated. These include: (1) Disposal index, (2) Productivity index, (3) Exhausted charge, (4) Impending charge, and (5) Replacement index. Workforce dimension and Workforce variation were also calculated.

The indicators are defined as follows:

\begin{tabular}{|l|l|l|}
\hline \multicolumn{1}{|c|}{ INDICATOR } & \multicolumn{1}{|c|}{ DESCRIPTION } & \multicolumn{1}{|c|}{ SOURCE } \\
\hline Disposal index & $\begin{array}{l}\text { The ratio between the number of cases defined in one year and the sum of the } \\
\text { cases which occurred in the year and the cases pending at the start of the } \\
\text { period }\end{array}$ & DG-Stat \\
\hline $\begin{array}{l}\text { Productivity } \\
\text { index }\end{array}$ & The number of cases defined by each judge per year & $\begin{array}{l}\text { DG-Stat } \\
\text { C.S.M. }\end{array}$ \\
\hline $\begin{array}{l}\text { Exhausted } \\
\text { charge }\end{array}$ & The number of cases assigned to each judge per year & $\begin{array}{l}\text { DG-Stat } \\
\text { C.S.M. }\end{array}$ \\
\hline $\begin{array}{l}\text { Impending } \\
\text { charge }\end{array}$ & The number of pending cases for each judge at the end of the period & $\begin{array}{l}\text { DG-Stat } \\
\text { C.S.M. }\end{array}$ \\
\hline Replacement & The ratio between the number of cases defined in one year and the number of & DG-Stat \\
\hline
\end{tabular}




\begin{tabular}{|l|l|l|}
\hline index & cases assigned in the same period & \\
\hline $\begin{array}{l}\text { Workforce } \\
\text { dimension }\end{array}$ & $\begin{array}{l}\text { The binomial variable which has 0 value if the number of judges in the } \\
\text { sub-district is lower than the national average, and a value of } 1 \text { if it is higher }\end{array}$ & C.S. \\
\hline $\begin{array}{l}\text { Workforce } \\
\text { variation }\end{array}$ & The difference in the number of judges in two different years. & C.S.M. \\
\hline
\end{tabular}

The disposal index is considered as a dependent variable as the authors believe it represents the best proxy of system performance at sub-district level.

In order to explore the relationship between the disposal index and the other indicators, a regression model could have been estimated. However, two problems arise: first, the job indicators (productivity, exhausted charge, impending charge and the replacement index) have strong collinearity factors because they are calculated on the same baseline items as the disposal index. Moreover, the data available are observed in a temporal series within a longitudinal framework, with a probable auto-correlation and other problems, which are typical of repeated measurements. The nature of the correlation is the outcome of the parameterization of the growth factors and, consequently, is part of the longitudinal model itself.

To resolve this problem, at least one index, the impending charge, was removed from the model (even if it was the least correlated to the disposal index) and a "repeated measurement model" was applied. The chosen model is known as a "hierarchical", "multilevel", "growth" or "mixed-effects" model and it provides a feasible approach for the correct treatment of growth data in cases of repeated measures on statistical units over time.

A Multilevel Growth Model (MGM) analyses random effects. Intercepts and slopes describe individual trajectories over time and they vary between individuals, assuming that observations on the same unit are correlated. Time is assumed as a fixed effect "nested" within the subjects.

The model adopted is useful to facilitate the study of the effects of covariates of development at every level of nesting.

The model starts with individual trajectories, which are referred to as the Level 1 (or within-units) model for intra-individual change, assumed as following a linear trend:

$$
\mathrm{y}_{\mathrm{ti}}=\pi_{0 \mathrm{i}}+\pi_{1 \mathrm{i}} \text { time }_{\mathrm{ti}}+\mathrm{r}_{\mathrm{ti}}
$$

where:

$\mathrm{y}_{\mathrm{ti}}$ represents the disposal index at time $\mathrm{t}(\mathrm{t}=1, \ldots, \mathrm{k})$ for the $\mathrm{i}$-th sub-district $(\mathrm{i}=1, \ldots, \mathrm{n})$, time $_{\mathrm{ti}}$ is the variable time indexed by number of longitudinal observations (in this case, years) and sub-district, $\pi_{0 \mathrm{i}}$ and $\pi_{1 \mathrm{i}}$ are the intercept (mean of disposal index at time $\mathrm{e}_{\mathrm{i}}=0$ ) and slopes (rate of increase over time) for subject i.

A Level 2 (or between-units) model has to be specified for inter-individual differences. This model decomposes the individual intercept and slopes $\left(\pi_{0 \mathrm{i}}\right.$ and $\left.\pi_{1 \mathrm{i}}\right)$ into: (i) the mean values of the parameter across individuals $\left(\beta_{00}\right.$ and $\beta_{10}$ ); (ii) the effect of a set of individual 
characteristics ( $\mathrm{x}_{\mathrm{ki}}$ with $\beta_{\mathrm{k}}$ associated parameter) of subject $\mathrm{i}$; (iii) the individual random effects $\left(\mathrm{u}_{0 \mathrm{i}}\right.$ and $\left.\mathrm{u}_{1 \mathrm{i}}\right)$ :

$$
\pi_{0 \mathrm{i}}=\beta_{00}+\sum \beta_{\mathrm{k}} \mathrm{x}_{\mathrm{ki}}+\mathrm{u}_{0 \mathrm{i}} ; \quad \pi_{1 \mathrm{i}}=\beta_{10}+\sum \beta_{\mathrm{k}} \mathrm{x}_{\mathrm{ki}}+\mathrm{u}_{1 \mathrm{i}}
$$

Each equation presents errors at all nested levels: $r_{t i}$ is the random effect of time $t$ on the trajectory of outcome evolution for sub-district $i$, while $u_{0 i}$ and $u_{1 i}$ are the random effects of sub-district $i$ with respect to the mean trajectory across the sub-districts.

Even though several models were identified, only the best model (MGM with a "scaled identity" covariance structure) is shown here.

As far as we know, this is the first attempt to apply this model to empirically estimate the role the number of judges has on judiciary system performance.

\section{Findings and Discussion}

The methodology was applied to evaluate the performance of the Italian judicial sub-districts in a dynamic way. All indicators described are assumed to be covariates, while the status of the workforce, whether under or over the average workforce, is a binomial factor (see Table 1).

In this model, each increased point of productivity, exhausted charge or replacement index leads to a fractional, but significant, increment in the disposal index. However, sub-districts with a workforce under the national average have, on average, a ten points higher disposal index. This effect is partially corrected by the interaction with the exhausted charge. In sub-districts with an over- average workforce, the disposal index increases by 0.05 points for each process exhausted, versus 0.03 for the others. These results refer to each observation.

The multilevel co-variance structure shows the important contribution of the longitudinal effect (years), but also the significant variability in workforce status, of changes in the workforce, and, due to its relation with time, of the impending charge (the indicator that was removed from the Level 1 model). All these variables significantly influence the disposal index over time.

This growth model almost totally explains the variability in the disposal index over time and between sub-districts, as it has a Pseudo R-square $=0.993$, as well as the relative misfit index (i.e. the square root of the sum of residual square roots divided by the sum of the original data) which is less than $1 \%$. (see Tables 2 and 3 ).

The results show that, although the contribution of the judicial workforce on the performance of the system is significant, it cannot explain all the differences in performance which exist in the Italian sub-districts.

The differences in productivity observed among the Italian judicial districts and sub-districts show that it is possible to improve the quality of the whole system through a more rational organization of resources. This depends on at least two important elements/factors which could help to improve the performance of a larger than average sub-district. These are: (i) more organizational intervention and (ii) the widespread use of case management techniques. 


\section{Ml Macrothink}

Business and Economic Research

ISSN 2162-4860

2016, Vol. 6, No. 1

The latter is required to manage the workload better and so increase performance without expending more effort.

On this point, Beenstock and Haitovsky (2004) demonstrate that the growth in productivity is largely endogenous rather than exogenous and that it depends on the adoption of case management techniques and "... autonomous technical progress in case management, which has enabled judges to increase their productivity without expending more effort” (pg. 366). Following this approach the ability to manage (at an individual level) could play an important role.

Table 1. The Indicators

\begin{tabular}{|c|c|c|c|c|c|}
\hline & & & & Min & $\operatorname{Max}$ \\
\hline \multirow{2}{*}{ Disposal } & \multirow{2}{*}{$=$} & Defined & \multirow{2}{*}{$* 100$} & \multirow{2}{*}{22} & \multirow{2}{*}{73} \\
\hline & & Occurred + Pending & & & \\
\hline \multirow{2}{*}{ Productivity } & \multirow{2}{*}{$=$} & Defined & \multirow{2}{*}{$* 100$} & \multirow{2}{*}{119} & \multirow{2}{*}{1578} \\
\hline & & Judges & & & \\
\hline \multirow{2}{*}{ Exhausted } & \multirow{2}{*}{$=$} & Occurred & \multirow{2}{*}{$* 100$} & \multirow{2}{*}{104} & \multirow{2}{*}{1714} \\
\hline & & Judges & & & \\
\hline \multirow{2}{*}{ Impending } & \multirow{2}{*}{$=$} & Pending & \multirow{2}{*}{$* 100$} & \multirow{2}{*}{144} & \multirow{2}{*}{2796} \\
\hline & & Judges & & & \\
\hline \multirow{2}{*}{ Replacement } & \multirow{2}{*}{$=$} & Defined & \multirow{2}{*}{$* 100$} & \multirow{2}{*}{63} & \multirow{2}{*}{186} \\
\hline & & Occurred & & & \\
\hline \multicolumn{3}{|c|}{ Workforce dimension } & & 0 & 1 \\
\hline \multicolumn{3}{|c|}{ Workforce variation } & & -41 & 78 \\
\hline
\end{tabular}

Table 2. Estimates of Fixed Effects (Dependent Variable: disposal index)

\begin{tabular}{|l|l|l|c|c|c|}
\hline \multicolumn{1}{|c|}{ Effect } & \multicolumn{1}{c|}{$\beta$} & & & & \\
\hline Productivity & Estimate & Std. Err. & \multicolumn{1}{c|}{$d f$} & \multicolumn{1}{c|}{$t$} & p-value \\
\hline Replacement index & 0.0183 & 0.0023 & 498.99 & 7.830 & $<0.001$ \\
\hline Exhausted charge & 0.1178 & 0.0146 & 499.21 & 8.073 & $<0.001$ \\
\hline Under-average workforce & 0.0300 & 0.0043 & 569.64 & 6.955 & $<0.001$ \\
\hline Over-average workforce & 37.4830 & 1.7075 & 625.88 & 21.952 & $<0.001$ \\
\hline Exhausted charge * (workforce=over-average) & 27.6849 & 2.7949 & 472.12 & 9.905 & $<0.001$ \\
\hline
\end{tabular}

Table 3. Estimates of Covariance Parameters (Dependent Variable: disposal index)

\begin{tabular}{|l|l|l|l|l|}
\hline & $\begin{array}{c}\text { Variance } \\
\text { estimate }\end{array}$ & Std. Err. & Wald Z & p-value \\
\hline Repeated Measures (years) & 1.0335 & 0.0774 & 13.349 & $<0.001$ \\
\hline Over-average workforce & 67.4925 & 10.4209 & 6.477 & $<0.001$ \\
\hline Workforce variation & 0.0019 & 0.0005 & 4.108 & $<0.001$ \\
\hline Impending charge & 0.0010 & 0.0001 & 7.604 & $<0.001$ \\
\hline
\end{tabular}




\section{Conclusions}

This paper focuses on the behaviour of judges and their contribution in determining the performance of the system from a theoretical point of view. Moreover, the paper examines whether the productivity differences among Italian sub-districts are caused by an inefficient distribution of resources.

An econometric model was applied in order to explore the contribution of the number of judges at sub-district level. The analyses were conducted using a Multilevel Growth Model (MGM) which is a useful way to examine change over time when data is nested across two levels.

Although the results support the hypothesis that the judicial workforce significantly contributes to the performance of the system, they also suggest that this does not sufficiently explain the differences observed in the Italian sub-districts performance.

These could be explained by the other factors, which contribute to defining the supply of the judicial system, which are the organizational structure of the courts and the incentives for operators.

In recent years much has been done to improve the performance of the Italian judicial system. The several legislative measures adopted include the revision of the judicial geography $\mathrm{y}^{3}$, telematic processes ${ }^{4}$, and compulsory conciliation ${ }^{5}$. These aimed to improve the performance of the system through a more efficient organization of resources.

Many more proposals relate specifically to the role of judges and the organization of the courts.

The authors believe the following are among the most important because they are also linked to the existence of individual incentives:

- To link the career progression of judges to some indices of specialization and productivity. The policies that have been adopted since the nineteen-fifties have meant that the career progression of judges coincides with seniority, thereby eliminating some important incentives to improve professional quality. It is true that the rules of career progression significantly and unavoidably interact with those that ensure the independence of the judiciary and that a balance between two key priorities - professional quality and impartiality of the judge - is difficult to achieve. Encouraging specialization that allows development in the vocational training of the magistrate through a process of "learning by doing" can help to get around the difficulty, at least in part.

- To link the career progression of judges (with reference to civil justice) to their ability to promote conciliatory solutions and sanction improper conduct during the proceedings. For many of the issues discussed in civil courts a more efficient solution could be found in

\footnotetext{
${ }^{3}$ Decree: February $19^{\text {th }}, 2014$, n. 14

4 The "regulation concerning the technical rules for the adoption of information and communication technologies in the civil and criminal proceeding" was adopted with the Decree n. 44 of February $21^{\text {st }}, 2011$,

${ }^{5}$ Decree: no. 28 , of March $4^{\text {th }}, 2010$.
} 


\section{Macrothink Institute ${ }^{\text {th }}$}

alternative forms of justice if the actors involved were informed that the proceedings could last more than two years, generating costs similar to the compensation set by the judge.

- To transform the presidents of the courts into real court managers. A managerial administration would be necessary in order to promote and verify the "productivity" of individual judges and to regulate their direct professional responsibility.

Lastly, but not less significant, is the important role which the rules for transferring judges plays on court performance. In Italy a judge could be moved to a different court every three years. According to Coviello et al. (2014) rationally, this possibility affects the system performance which then increases in relation to (i) the number of transfers per year, (ii) the time that a new judge needs to resolve a dispute which another judge had begun and (iii) the pending charge for each judge. From this point of view, the organizational aspect of work also becomes a crucial factor.

\section{References}

Beenstock, M., Haitovsky, Y., (2004). Does the appointment of judges increase the output of the judiciary?. International Review of Law and Economics, 24, 351-369. http://dx.doi.org/10.1016/j.irle.2004.10.006

Buscaglia, E., Dakolias, M., (1999). Comparative International Study of Court Performance Indicators. The World Bank, Legal Department.

Buscaglia, E., (2006). Comparative international study of court performance indicators: a descriptive and analytical account. Available at SSRN 931394.

Castro, A., (2009). Court performance in Brazil: Evidence from judicature-level data. Midwest Political Science Association 67th Annual National Conference, The Palmer House Hilton, Chicago. http://dx.doi.org/10.2139/ssrn.2612941

CEPEJ (Council of Europe's European Commission for the Efficiency of Justice), 2012. Report on the evaluation of the judicial system.

Cohen, A., Klement, A., Neeman, Z., (2013). Judicial Decision Making: A Dynamic Reputation Approach. Available: http://www.law.yale.edu

Cooter, R. D., (1983). The objectives of private and public judges. Public Choice, 41, 107-137. http://dx.doi.org/10.1007/BF00124053

Coviello, D., Ichino, A., Persico, N., (2014). Time Allocation and Task Juggling, American Economic Review, 104(2), 609-23. http://dx.doi.org/10.1257/aer.104.2.609

Dakolias, M., (1999). Court performance around the world: A comparative perspective. Washington, DC: The World Bank. http://dx.doi.org/10.1596/0-8213-4436-6

Deyneli, F., (2012). Analysis of relationship between efficiency of justice services and salaries of judges with two-stage DEA method. European Journal of Law and Economics 34(3), 477-493. http://dx.doi.org/10.1007/s10657-011-9258-3

Di Vita, G., (2010). Production of laws and delays in court decisions. International Review of 
Law and Economics 30(3), 276-281. http://dx.doi.org/10.1016/j.irle.2010.03.006

Di Vita, G., (2012). Normative complexity and the length of administrative disputes: evidence from Italian regions. European Journal of Law and Economics, 34(1), 197-213. http://dx.doi.org/10.1007/s10657-010-9182-y

Gurrieri, A. R., Lorizio, M., (2014a). Giustizia civile, sviluppo economico e competitività del sistema paese. In: Crocetta, C., (ed.). La situazione della giustizia in Italia, Milano: Franco Angeli, 97-117.

Gurrieri, A. R., Lorizio, M., (2014b). Efficiency of Justice and Economic Systems, Procedia Economics and Finance, 17, 104-112. http://dx.doi.org/10.1016/S2212-5671(14)00884-3

Gurrieri, A. R., Lorizio, M., (2015). The Efficiency and Demands of the Italian Justice System, Journal of Statistical Science and Application, 3(3-4), 31-38. http://dx.doi.org/10.17265/2328-224X/2015.34.001

Leonardi, M., Rancan, M. R., (2010). Risorse e performance nella giustizia civile; Europa Lavoro Economia. Supplemento mensile di AREL Attività Parlamentare e Legislativa. February.

Marchesi, D., (2003). Litiganti, avvocati e magistrati. Diritto ed economia del processo civile. Bologna: Il Mulino.

Miceli, T. J., Cosgel, M. M. (1994). Reputation and Judicial Decision- Making. Journal of Economic Behavior and Organization, 31-51. http://dx.doi.org/10.1016/0167-2681(94)90095-7

Mitsopoulos, M., Pelagidis, T., (2010). Greek appeals courts' quality analysis and performance. European Journal of Law and Economics, 30(1), 17-39. http://dx.doi.org/10.1007/s10657-009-9128-4

Murrell, P., (2001). Demand and supply in Romanian commercial courts: Generating information for institutional reform. Available at SSRN 280428. http://dx.doi.org/10.2139/ssrn.280428

North, D. C., (1990). Institutions, Institutional Change and Economic Performance, Cambridge: Cambridge University Press. http://dx.doi.org/10.1017/CBO9780511808678

Palumbo, G., Sette, E., (2008). Career Concerns and Delayed Decisions: An Application to Courts. Banca d'Italia, Mimeo.

Posner, R. A., (2008). How judges think. Cambridge, MA: Harvard University Press.

Posner, R. A., (1993). What do judges and justices maximize? (The same thing everybody else does). Supreme Court Economic Review, 3, 1-41. http://dx.doi.org/10.1086/scer.3.1147064

Rosales-López, V., (2008). Economics of court performance: An empirical analysis. European Journal of Law and Economics, 25(3), 231-251. 
http://dx.doi.org/10.1007/s10657-008-9047-9

Schneider, M. R., (2005). Judicial career incentives and court performance: an empirical study of the German labour courts of appeal. European Journal of Law and Economics, 20(2), 127-144. http://dx.doi.org/10.1007/s10657-005-1733-2

Scott, K., (2006). Understanding Judicial Hierarchy: Reversal and Behaviour of Intermediate Appellate Judges. Law \& Society Review, 40(1), 163-192. DOI: $10.1111 / \mathrm{j} .1540-5893.2006 .00249$

Stramaglia, A., (2014). Inefficienze della giustizia civile: profili economici, In: Crocetta, C., (ed.) La situazione della giustizia in Italia. Analisi e prospettive. Milano: Franco Angeli.

Szego, B. (2008). L'inefficienza degli appelli civili in Italia: regole processuali o altro? Mercato Concorrenza Regole, 10(2), 283-316. DOI: 10.1434/27739

Williamson, O. E., (1985). The economic institutions of capitalism. New York: Free Press.

Yeung, L. L., Azevedo, P. F., (2011). Measuring efficiency of Brazilian courts with data envelopment analysis (DEA). IMA Journal of Management Mathematics, 22(4), 343-356. http://dx.doi.org/10.1093/imaman/dpr002

\section{Copyright Disclaimer}

Copyright for this article is retained by the author(s), with first publication rights granted to the journal.

This is an open-access article distributed under the terms and conditions of the Creative Commons Attribution license (http://creativecommons.org/licenses/by/3.0/). 